\title{
Cats cloned from fetal and adult somatic cells by nuclear transfer
}

\author{
X J Yin, H S Lee, Y H Lee, Y I Seo, S J Jeon, E G Choi, S J Cho, S G Cho, W Min, S K Kang ${ }^{1}$, \\ W S Hwang and I K Kong
}

Department of Animal Science and Technology, College of Agriculture and Life Science, Sunchon National University, 315 Maegok-dong, Sunchon, JeonNam Province 540-742, South Korea and ${ }^{1}$ Department of Theriogenology and Biotechnology, College of Veterinary Medicine, Seoul National University, San 56-1, Shilim-Dong, Kwanak-Gu, Seoul 151-742, South Korea

Correspondence should be addressed to I K Kong; Email: ikong@sunchon.ac.kr

\begin{abstract}
This work was undertaken in order to study the developmental competence of nuclear transfer (NT) into cat embryos using fetal fibroblast and adult skin fibroblast cells as donor nuclei. Oocytes were recovered by mincing the ovaries in Hepes-buffered TCM199 and selecting the cumulus oocyte complexes (COCs) with compact cumulus cell mass and dark color. Homogenous ooplasm was cultured for maturation in TCM199+10\% fetal bovine serum (FBS) for $12 \mathrm{~h}$ and used as a source of recipient cytoplast for exogenous somatic nuclei. In experiment 1 , we evaluated the effect of donor cell type on the reconstruction and development of cloned embryos. Fusion, first cleavage and blastocyst developmental rate were not different between fetal fibroblasts and adult skin cells $(71.2$ vs $66.8 ; 71.0$ vs $57.6 ; 4.0$ vs $6.1 \%$ respectively; $P<0.05)$. In experiment 2 , cloned embryos were surgically transferred into the oviducts of recipient queens. One of the seven recipient queens was delivered naturally of 2 healthy cloned cats and 1 stillborn from fetal fibroblast cells of male origin 65 days after embryo transfer. One of three recipient queens was delivered naturally of 1 healthy cloned cat from adult skin cells of female origin 65 days after embryo transfer. The cloned cats showed genotypes identical to the donor cell lines, indicating that adult somatic cells can be used for feline cloning.

Reproduction (2005) 129 245-249
\end{abstract}

\section{Introduction}

Many animal species including sheep (Wilmut et al. 1997), cattle (Cibelli et al. 1998, Kato et al. 1998), goat (Baguisi et al. 1999), mice (Wakayama et al. 1998), pig (Polejaeva et al. 2000, Yin et al. 2002a, 2003), rabbit (Chesne et al. 2002), mule (Woods et al. 2003), horse (Galli et al. 2003) and rat (Zhou et al. 2003) have been successfully cloned using somatic cells. Up to now, cats have been considered difficult to clone. Indeed, although one group reported the birth of a cloned cat with donor cumulus cells (Shin et al. 2002), no group has obtained feline cloning using fetal and skin fibroblasts as the nuclear donor (Skrzyszowska et al. 2002, Gomez et al. 2003, Kitiyanant et al. 2003, Li et al. 2003, Wen et al. 2003). We report here the successful cloning of cats from male fetal fibroblasts and female adult somatic cells. Four cats were naturally delivered from the two cell types. Our results will contribute to the rescue of endangered feline species.

\section{Materials and Methods}

Unless otherwise indicated, all chemicals were purchased from Sigma Chemical Co. (St. Louis, MO, USA).

\section{Animal care and use}

Domestic hybrid female cats were used for this study. The cats were cared for in facilities and using procedures which exceed the standards established by the Sunchon National University Association for Accreditation of Laboratory Animal Care.

\section{Ovary recovery and in vitro maturation}

Healthy mature female cats were selected for superovulation. Each cat was injected i.m. with $200 \mathrm{IU}$ pregnant mare serum gonadotropin (PMSG; Daesung, Kyungg-Do, Korea) and $100 \mathrm{IU}$ human chorionic gonadotropin (hCG; Daesung) 4 days apart. Ovaries were removed from the tract and minced with a scalpel blade in TALP-Hepes to release cumulus oocyte complexes (COCs). The collected 
oocytes were matured in TCM199 (M-7528) supplemented with $10 \%$ fetal bovine serum (FBS, Gibco) and $1 \%$ penicillin G/streptomycin (P/S; P-4333) for $12 \mathrm{~h}$ at $38{ }^{\circ} \mathrm{C}, 5 \%$ $\mathrm{CO}_{2}$ in air.

\section{Cell culture and preparation of donor cells}

Fetal fibroblast cells were isolated from a domestic cat fetus $(2.5 \mathrm{~cm}$ in length) acquired by ovariohysterectomy. Adult fibroblast cells were cultured from ear skin tissue of a female cat (gold and tan spots over white coat color). The cells were cultured in DMEM+10\% FBS at $38{ }^{\circ} \mathrm{C}, 5 \%$ $\mathrm{CO}_{2}$ in air. After confluence, the cells were passaged 1 to 9 times, collected, and stored in liquid nitrogen. To induce a quiescent state, semi-confluent fibroblast cells were cultured in DMEM+0.5\% FBS for an additional 3 days before use.

\section{Nuclear transfer}

The cumulus cells from oocytes were removed by gently pipetting in TCM199 supplemented with $0.1 \%$ hyaluronidase. The denuded oocytes were cultured in TCM199 supplemented with $0.2 \mu \mathrm{g} / \mathrm{ml}$ demecolcine for $1 \mathrm{~h}$ and placed in TCM199 containing $5 \mu \mathrm{g} / \mathrm{ml}$ cytochalasin B and $0.2 \mu \mathrm{g} / \mathrm{ml}$ demecolcine. The protrusion of the polar body and chromatin plate was removed with a beveled pipette mounted on Narishige micromanipulators while viewing with a Nikon microscope, as previously described (Yin et al. 2002a, 2003). Donor cells were trypsinized using a $1 \%$ trypsin-EDTA solution and placed in $\mathrm{Ca}^{2+}{ }_{-}, \mathrm{Mg}^{2+}$-free D-PBS supplemented with $0.3 \%$ BSA. Micromanipulation was used to place a single nuclear donor cell into the perivitelline space of enucleated ova. The ovum/cell couplets were equilibrated in $0.3 \mathrm{M}$ mannitol containing $0.1 \mathrm{mM} \mathrm{Mg}^{2+}$ and transferred to an electrofusion chamber containing the same medium. Cell fusion was induced by $2.0 \mathrm{kV} / \mathrm{cm} 60 \mu \mathrm{s}$ DC pulses delivered by an Electro cell fusion generator (Nepagene, Chiba, Japan) applied 2 times. The couplets were removed from the fusion chamber, washed, and incubated in TCM199 supplemented with $0.3 \% \mathrm{BSA}$ at $38{ }^{\circ} \mathrm{C}, 5 \% \mathrm{CO}_{2}$ in air. One hour after electrofusion, fused couplets were removed from the incubator and equilibrated in $0.3 \mathrm{mM}$ mannitol containing $0.1 \mathrm{mM} \mathrm{Ca}^{2+}$ and $0.1 \mathrm{mM} \mathrm{Mg}^{2+}$, placed into a fusion chamber containing the same medium and electropulsed with $1.0 \mathrm{KV} / \mathrm{cm} 20 \mu \mathrm{s}$ DC pulses, 0.1 seconds apart, applied 2 times. The fused couplets were washed and incubated for $4 \mathrm{~h}$ in TCM199 supplemented with $0.3 \% \mathrm{BSA}$ and $5 \mu \mathrm{g} / \mathrm{ml}$ cytochalasin $\mathrm{B}$ at $38{ }^{\circ} \mathrm{C}, 5 \% \mathrm{CO}_{2}$ in air. Cloned embryos were cultured in TCM199+0.3\% BSA until embryo transfer.

\section{In vitro culture of nuclear transfer embryos and cell count}

Fused couplets were cultured in $50 \mu$ l droplets of TCM199 supplemented with $0.4 \%$ BSA under mineral oil in a humidified atmosphere of $5 \% \mathrm{CO}_{2}$ for 6 days. Cleavage and blastocyst development of nuclear transfer embryos was evaluated on day 1 (day $0=$ day of activation) and day 6 . The number of cells in the blastocysts was evaluated by fluorescence microscopy. The embryos were stained with Hoeschst 33342 and the cell nuclei were counted.

\section{Synchronization of recipient females and embryo transfer}

Cloned embryos were surgically transferred into the oviducts of recipient queens. Estrus synchronization of recipient queens was attained using the same hormone injection regimen described above. The cloned embryos at the one-cell stage after fusion or at the two- to four-cell stage after a day of culture were transferred into the oviducts of synchronized females and confirmed at the ovulated point on the ovary approximately $30 \mathrm{~h}$ after hCG injection. Pregnancy was determined by palpation 40 or 45 days after embryo transfer and confirmed by X-ray photography at 60 days.

\section{Microsatellite analysis}

Parentage analysis was performed on the cats obtained by nuclear transfer and the surrogate recipient females to confirm identify of the donor cells used for nuclear transfer. DNA was extracted from ear punches or tail clippings obtained from each newborn cat, recipients and donor cells. Five feline DNA microsatellite markers (FCA229, FCA290, FCA441, FCA201, and FCA224) were used to confirm the genetic identity of the cloned cats, the fetus and the skin cells as donor cells.

\section{Statistical analysis}

Data were analyzed by a General Linear Model technique (SAS, 1990). Statistical significance was established at the $P<0.05$ level.

\section{Results}

\section{Experiment 1. In vitro development of nuclear transfer embryos}

When matured eggs with a first polar body were treated with demecolcine for $1 \mathrm{~h}$, more than $70 \%$ of the eggs had a membrane protrusion and the chromosome mass migrated to a cortical location. Enucleation of the eggs with a small volume of cytoplasm was easy and the enucleation rate was high (123 out of $145 ; 85 \%$ ).

The in vitro development of nuclear transfer embryos reconstructed with fetal and adult fibroblast cells is shown in Table 1. Fusion rates were not different between fetal and adult fibroblast cells (71.2 vs $66.8 \% ; P<0.05)$. The proportion of reconstructed embryos that cleaved was higher in the fetal group compared with the adult group 
Table 1 In vitro development of nuclear transferred embryos from different cell lines.

\begin{tabular}{lcccccc}
\hline Donor cells & NT units & Fused $(\%)$ & Cultured & First cleavage $(\%)$ & Blastocyst $(\%)$ & The average number of cells \\
\hline Male fetal fibroblast & 174 & $124(71.2)^{\mathrm{a}}$ & 124 & $88(71.0)^{\mathrm{a}}$ & $5(4.0)^{\mathrm{a}}$ & 22.2 \\
Female skin fibroblast & 151 & $101(66.8)^{\mathrm{a}}$ & $33^{*}$ & $19(57.6)^{\mathrm{a}}$ & $2(6.1)^{\mathrm{a}}$ & 23.5 \\
\hline
\end{tabular}

Values with same superscripts were not significantly different $(P<0.05)$.

*Thirty three of 101 fused embryos were cultured in vitro, the rest of the fused embryos were transferred into a recipient.

(71.0 vs $57.6 \% ; P<0.05)$. Development to the blastocyst stage was not different using either type of karyoplast $(4.0$ vs $6.1 \%$ ). Total cell numbers for the five blastocysts produced using fetal fibroblasts were $23,31,17,12$ and 28. The blastocysts produced using adult fibroblasts had a total cell number of 20 and 27.

\section{Experiment 2. Cloned embryo transfer into recipient queens}

A donor fibroblast cell line was established from a fiveweek-old male fetus and passaged one to nine times for expansion in culture. These cells were cultured in DMEM+0.5\% serum for an additional three days before use of nuclear transfer and fusion with enucleated oocytes devoid of metaphase chromosomes by micromanipulation as described (Yin et al. 2002a, 2003). Cloned embryos at the one-cell stage (120 and 140 eggs) or at the two- to fourcell stage ( $n=30-90$ eggs) were transferred into seven synchronized recipients approximately $30 \mathrm{~h}$ after hCG treatment (Table 2). Recipient 7 received 140 cloned embryos, which were reconstructed with 9 passaged cells and maintained the pregnancy to term. Pregnancy was confirmed by X-ray photography one day before parturition. Two live kittens and one stillborn fetus were delivered naturally 65 days after embryo transfer. The birth weights of the cloned live cats at delivery were 96 and $84 \mathrm{~g}$ and the stillborn offspring weighed $56 \mathrm{~g}$. We suspected that the stillborn fetus was related to the palpation used to confirm pregnancy. Two cloned cats are still alive and healthy after 4 months (Fig. 1a). An adult somatic cell line was established from a 12-month-old female cat as described above. One hundred and forty-five cloned embryos at the two- to four-cell stage were transferred into three recipients. One recipient was confirmed pregnant after receiving 65 recon- structed embryos derived from one passaged cells and then produced one kitten (Fig. 1b) by natural delivery 65 days after embryo transfer. The birth weight of the cloned kitten was $102 \mathrm{~g}$. The kitten was vigorous at birth and appeared to be completely normal, but died three days post-parturition from starvation as it refused to suck colostrum. Pathological analysis of the cloned cat did not detect any abnormalities. Microsatellite analysis revealed that the donor cells were the source of the genetic material used to produce the newborn cats (Table 3).

\section{Discussion}

In the present study, we investigated the possibility of producing normal cloned cats by using fetal and adult somatic donor cells. This is the first time, to our knowledge, that normal cloned cats have been produced using fetal donor cells. The results of our experiment showed that fusion, cleavage and developmental rate to the blastocyst stage were similar to those reported previously (Skrzyszowska et al. 2002, Gomez et al. 2003, Kitiyanant et al. 2003, Wen et al. 2003). However, the quality of the blastocysts, based on the cell number, was poor in comparison with other reported experiments (Skrzyszowska et al. 2002, Gomez et al. 2003, Kitiyanant et al. 2003, Wen et al. 2003). In this study, we used a culture regime of TCM199 supplemented with $0.3 \%$ BSA for 6 days. It would seem that this in vitro culture system is not ideal for the culture of cloned cat embryos.

A major difference between the methods described here and those used to produce cloned kittens in a previous report (Shin et al. 2002) is the use of chemically assisted removal of maternal chromosomes, as in pig cloning (Yin et al. 2002a, 2003), and the transfer of large numbers of

Table 2 Production of cloned cats following nuclear transferred embryos into recipients.

\begin{tabular}{|c|c|c|c|c|c|c|}
\hline Donor cells & Passage number & Recipient & No. of transferred NT units (cell stage) & Delivery & No. of kittens & Sex of kittens \\
\hline \multirow[t]{7}{*}{ Fetal fibroblast } & P-9 & 1 & 30 (2,4-cell) & No & - & \\
\hline & P-9 & 2 & 44 (2,4-cell) & No & - & \\
\hline & P-9 & 3 & $34(2,4$-cell $)$ & No & - & \\
\hline & P-5 & 4 & 72 (2,4-cell) & No & - & \\
\hline & P-9 & 5 & $90(2,4$-cell $)$ & No & - & \\
\hline & P-9 & 6 & 120 (1-cell) & No & - & \\
\hline & P-9 & 7 & 140 (1-cell) & Yes & 1 stillborn \& 2 kittens & Male \\
\hline \multirow[t]{3}{*}{ Skin fibroblast } & P-1 & 1 & 40 (2,4-cell) & No & - & \\
\hline & P-1 & 2 & 65 (2,4-cell $)$ & Yes & 1 kittens & Female \\
\hline & P-1 & 3 & 40 (2,4-cell) & No & - & \\
\hline
\end{tabular}



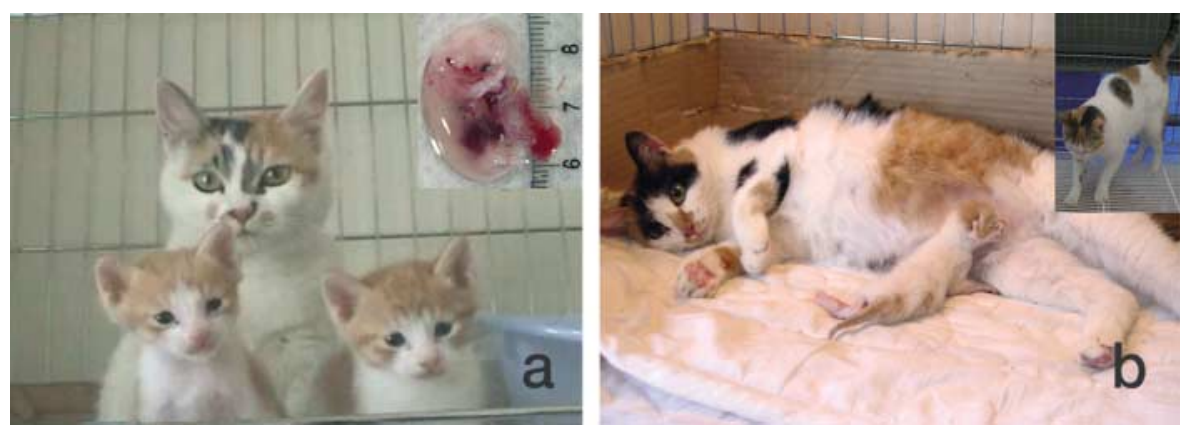

Figure 1 Cloned kittens with surrogate mother and nuclear donor (fetus or adult). (a) Surrogate mother and 2 cloned kittens; insert shows nuclear donor fetus. (b) Surrogate mother and a cloned kitten; insert shows nuclear donor cat.

Table 3 Analysis of feline genetic markers. Values represent the sizes (in base pairs) of the two versions of the amplified microsatellite DNA markers in each sample.

\begin{tabular}{|c|c|c|c|c|c|c|c|c|}
\hline \multirow[b]{2}{*}{ Feline markers } & \multicolumn{5}{|c|}{ Experiment 1 (tail tissue) } & \multicolumn{3}{|c|}{ Experiment 2 (tail tissue) } \\
\hline & Fetal cell & Surrogate queen & Kitten 1 & Kitten 2 & Kitten 3 & Skin cells & Surrogate queen & Kitten 1 \\
\hline FCA229 & ND & ND & ND & ND & ND & 170 & $163 / 170$ & 170 \\
\hline FCA290 & $213 / 215$ & 213 & $213 / 215$ & $213 / 215$ & $213 / 215$ & 213 & 213 & 213 \\
\hline FCA441 & $150 / 154$ & $150 / 159$ & $150 / 154$ & $150 / 154$ & $150 / 154$ & $150 / 154$ & ND & $150 / 154$ \\
\hline FCA201 & $151 / 155$ & $151 / 153$ & $151 / 155$ & $151 / 155$ & $151 / 155$ & 151 & 138 & 151 \\
\hline FCA224 & 175 & $153 / 175$ & 175 & 175 & 175 & $162 / 175$ & 162 & $162 / 175$ \\
\hline
\end{tabular}

ND, not determined.

embryos. Matured cat eggs treated with demicolcine had a membrane protrusion in which the condensed chromosome mass was located. Although the mechanisms of action of demicolcine are not clear, the appearance of the protrusion might be related to the condensation of maternal chromosomes. Such protrusions are observed in demicolcine-treated pig (Yin et al. 2002a, 2003) and rabbit (Yin et al. 2002b) eggs. This simple, chemically assisted method to remove maternal chromosomes makes it possible to produce a large number of nuclear-transferred eggs and efficiently to produce cloned cats.

To verify the genetic overlap between donor and cloned kittens, we performed parentage analysis with feline microsatellite markers among the cloned kittens, surrogate mothers and control cats. Analysis of five unlinked, highly polymorphic, feline-specific microsatellite loci confirmed that the kittens were clonal.

Although the coat color of the two cloned males (gold on white) resembled each other, the coat color of a cloned female (gold on white coat) was different from the donor female cat (gold and tan spots on white coat). We attribute this to the fact that the pigmentation pattern in multicolored animals is related not only to genetic factors, but also to developmental factors that are not controlled by genotype. The mitochondria inherited from the recipient oocyte would have a major influence over functions that depend on mitochondria gene expression (Holt et al. 2004).

In conclusion, we produced cloned cats from fetal fibroblast cells of a male donor and from adult somatic cells of a female donor by natural delivery. These results will have important applications in domestic cat breeding as well as in endangered felid species cloning, and will contribute to extending the use of cat models for biotechnological applications.

\section{Acknowledgements}

This work was supported by grants from PetClone Ltd. The authors gratefully acknowledge the help of $\mathrm{D} \vee \mathrm{M}$ Jong-Ki Paik for surgical assistance in the ovariohysterectomy and embryo transfer. We wish to thank Dr Erik Lillehoj for critical reading of the manuscript and helpful comments.

\section{References}

Baguisi A, Behboodi E, Melican DT, Pollock JS, Destrempes MM, Cammuso C, Williams JL, Nims SD, Porter CA, Midura P, Palacios MJ, Ayres SL, Denniston RS, Hayes ML, Ziomek CA, Meade HM, Godke RA, Gavin WG, Overstrom EW \& Echelard Y 1999 Production of goats by somatic cell nuclear transfer. Nature Biotechnology 17 456-461.

Chesne P, Adenot PG, Viglietta C, Baratte M, Boulanger L \& Renard JP 2002 Cloned rabbits produced by nuclear transfer from adult somatic cells. Nature Biotechnology 20 366-369.

Cibelli JB, Stice SL, Golueke PJ, Kane JJ, Jerry J, Blackwell C, Ponce de Leon FA \& Robl JM 1998 Cloned transgenic calves produced from nonquiescent fetal fibroblasts. Science $\mathbf{2 8 0} 1256-1258$.

Galli C, Lagutina I, Crotti G, Colleoni S, Turini P, Ponderato N, Duchi R \& Lazzari G 2003 A cloned horse born to its dam twin. Nature 424635.

Gomez MC, Jenkins JA, Giraldo A, Harris RF, King A, Dresser BL \& Pope CE 2003 Nuclear transfer of synchronized african wild cat somatic cells into enucleated domestic cat oocytes. Biology of Reproduction 69 1032-1041. 
Holt WV, Pickard AR \& Prather RS 2004 Wildlife conservation and reproductive cloning. Reproduction 127 317-324.

Kato Y, Tani T, Sotomaru Y, Kurokawa K, Kato J, Doguchi H, Yasue H \& Tsunoda Y 1998 Eight calves cloned from somatic cells of a single adult. Science $\mathbf{2 8 2} 2095-2098$.

Kitiyanant Y, Saikhun J \& Pavasuthipaisit K 2003 Somatic cell nuclear transfer in domestic cat oocytes treated with IGF-I for in vitro maturation. Theriogenology 59 1775-1786.

Li Z, Sabet MR, Zhou Q, Liu X, Ding W, Zhang Y, Renard JP \& Engelhardt JF 2003 Developmental capacity of ferret embryos by nuclear transfer using G0/G1-phase fetal fibroblasts. Biology of Reproduction $682297-2303$.

Polejaeva IA, Chen SH, Vaught TD, Page RL, Mullins J, Ball S, Dai Y, Boone J, Walker S, Ayares DL, Colman A \& Campbell KH 2000 Cloned pigs produced by nuclear transfer from adult somatic cells. Nature 407 505-509.

SAS Insitute Inc. 1990 The GLM procedure. SAS/STAT User's Guide, Version 6 (4th Edn. Vol. 2.) Carog, USA: SAS Institute Inc.

Shin TY, Kraemer D, Pryor J, Liu L, Rugila J, Howe L, Buck S, Murphy K, Lyons L \& Westhusin M 2002 A cat cloned by nuclear transplantation. Nature $\mathbf{4 1 5} 859$.

Skrzyszowska M, Katska L, Rynska B, Kania G, Smorag Z \& Pienkowski M 2002 In vitro developmental competence of domestic cat embryos after somatic cloning: a preliminary report. Theriogenology 58 1615-1621.

Wakayama T, Perry AC, Zuccotti M, Johnson KR \& Yanagimachi R 1998 Full term development of mice from enucleated oocytes injected with cumulus cell nuclei. Nature 394 369-374.

Wen DC, Yang CX, Cheng Y, Li JS, Liu ZH, Sun QY, Zhang JX, Lei L, Wu YQ, Kou ZH \& Chen DY 2003 Comparison of developmental capacity for intra- and interspecies cloned cat (Felis catus) embryos. Molecular Reproduction and Development 66 38-45.

Wilmut I, Schnieke AE, McWhir J, Kind AJ \& Campbell KHS 1997 Viable offspring derived from fetal and adult mammalian cells. Nature 385 810-813.

Woods GL, White KL, Vanderwall DK, Li GP, Aston KI, Bunch TD, Meerdo LN \& Pate BJ 2003 A mule cloned from fetal cells by nuclear transfer. Science 3011063.

Yin XJ, Tani T, Yonemura I, Kawakami M, Miyamoto K, Hasegawa R, Kato Y \& Tsunoda Y 2002a Production of cloned pigs from adult somatic cells by chemically assisted removal of maternal chromosomes. Biology of Reproduction 67 442-446.

Yin XJ, Kato Y \& Tsunoda Y 2002b Effect of delayed enucleation on the developmental potential of nuclear-transferred oocytes receiving adult and fetal fibroblast cells. Zygote 10 217-222.

Yin XJ, Cho SK, Park MR, Im YJ, Park JJ, Bhak JS, Kwon DN, Jun SH, Kim NH \& Kim JH 2003 Nuclear remodeling and the developmental potential of nuclear transferred porcine oocytes under delayedactivated conditions. Zygote 11 167-174.

Zhou Q, Renard JP, Fries GL, Brochard V, Beaujean N, Cherifi Y, Fraichard A \& Cozzi J 2003 Generation of fertile cloned rats by regulating oocyte activation. Science 3021179.

Received 30 June 2004

First decision 18 August 2004

Revised manuscript received 26 August 2004

Accepted 7 October 2004 